\title{
EVALUATING THE ROLES AND COMPETENCIES THAT ARE CRITICAL CONSIDERATIONS FOR MANAGEMENT DEVELOPMENT
}

\section{Authors:}

Patsy Govender

Sanjana B. Parumasur ${ }^{1}$

\section{Affiliations:}

${ }^{1}$ Discipline of Human

Resource Management,

University of KwaZulu-

Natal, South Africa

Correspondence to:

Sanjana Parumasur

email:

Brijballs@ukzn.ac.za

Postal address:

School of Management,

University of KwaZulu-

Natal, Private Bag

X54001,Westville 4000,

South Africa

\section{Keywords:}

Competing Values

Framework (CVF);

managerial competencies; managerial roles;

creating master managers; managerial effectiveness

\section{Dates:}

Received: 04 June 2009

Accepted: 09 Nov. 2009

Published: 03 June 2010

How to cite this article: Govender, P., \&

Parumasur, S. (2010).

Evaluating the roles and competencies that are critical considerations for management development. SA Journal of Industrial Psychology/SA Tydskrif vir Bedryfsielkunde, 36(1), Art. \#835, 11 pages.

DOI: 10.4102/sajip v36i1.835

This article is available at: http://www.sajip.co.za

(C) 2010. The Authors. Licensee: OpenJournals Publishing. This work is licensed under the Creative Commons Attribution License.

\section{ABSTRACT}

Orientation: If managerial roles/competencies are evaluated in an organisation, shortfalls in managerial functions can serve as areas for management development thereby enabling the potential to create master managers.

Research purpose: This study assesses the extent to which the current management cadre in a public sector division possesses the eight managerial roles/competencies (mentor, facilitator, monitor, co-ordinator, director, producer, broker, innovator) needed for effective management with the aim of identifying areas for management development. It also aims to assess whether the managerial roles relate to each other.

Motivation for the study: In order to avoid a 'hit and miss' approach to management development it is important to assess managerial roles/competencies to effectively identify areas for enhancement.

Research design, approach and method: The empirical analysis entailed data collection through the use of questionnaires, administered to a sample of 202 from a population of 400 managers, drawn using the stratified random sampling technique, thereby generating a $51 \%$ response rate. Data were analysed using descriptive and inferential statistics.

Main findings: The results indicate that managers in this public sector division are fulfilling the managerial roles in varying degrees, though not optimally. They do not display optimal paradoxical capability and behaviour complexity. Furthermore, the eight roles/competencies are interconnected. Managerial level, age and race were found to influence the extent to which managers possess and display various competencies.

Practical/managerial implications: The interconnectedness of the managerial roles/competencies implies that effective leaders should be ambidextrous in a figurative sense. Based on the results, a framework is generated that identifies areas for improvement in the managerial competencies required to ensure managerial effectiveness and hence presents skills to be developed or areas for management development in order to enhance each managerial role.

Contribution/value-add: The need for managers to be able to display optimal paradoxical capabilities and behavioural complexities is becoming more and more pronounced. This study highlights potential areas for management development, thereby contributing to managerial effectiveness.

\section{INTRODUCTION}

Organisational challenges place new and increasing demands on managers who have to develop new competencies in order to proactively recognise opportunities and manage challenges by suitably moulding the organisation's strategy. Undoubtedly, effective managers have become a requisite for continuing self-renewal and eventual organisational survival. Managers need to have a futuristic vision that focuses on high performance standards, increasing market share and gaining a competitive advantage while facing the challenges of globalisation. One way to accomplish this is by ensuring an effective management cadre through effective management development. With this in mind, this study aims to assess the extent to which current managers possess and display the eight managerial roles needed for effective management, as outlined in the Competing Values Framework of Quinn, Faerman, Thompson and McGrath (2003) and to identify areas for management development.

Environmental challenges influencing organisational performance compel managers to monitor the external environment for opportunities and threats and to constantly ensure the flexibility needed for quick reactions to challenges (Gómez-Mejía, Balkin \& Cardy, 2004). The global economy, the emergence of the internet, e-business revolution, the evolution of product quality and workforce diversity (GómezMejía et al., 2004; Kreitner, 2007) are challenges necessitating workplace changes, instigating a dramatic shift from a hierarchical management style to a flexible structure with interdependent and thoughtprovoking processes. Proactive managers see changes as challenges and as opportunities to mould the organisation's strategy. Amid daunting competitive challenges in a grim time, today's managers are immersed in fuelling organisational processes, nurturing innovations and visualising organisational goals.

This era of the new economy characterised by speed, customer satisfaction and quality is emphasising important intangible assets such as knowledge and human capital (Becker, Huselid \& Ulrich, 2001 cited in Kreitner, 2007). Today's empowered employees are engaged in generic activities such as problem-solving and decision-making. For new job requirements, employees need to be au fait with knowledge and skills and they expect managers to provide continuity and quality leadership to 
ensure continuous improvements. Visionary leaders with the ability to create a realistic vision of the future (Robbins, 2003) and managerial effectiveness with a focus on standards of performance on quantity and quality (Mullins, 2002) are essential to equip organisations to hone renewal and face the challenges of globalisation. Management development is selfdevelopment and competent managers are required to deliver the performance expected of a global player in a ferocious business world (Meyer et al., 2007). This journey towards mastery is highlighted by Quinn et al. (2003), who present eight managerial roles and twenty-four competencies.

The Competing Values Framework, a framework of managerial competence (Quinn et al., 2003), provides the foundation in developing managerial competencies and master managers. According to this framework, the following eight roles are critical ingredients for creating master managers: mentor, facilitator, monitor, co-ordinator, director, producer, broker and innovator (Quinn et al., 2003). As the forthcoming theoretical framework unfolds, the competencies are placed into perspective and their interrelations are emphasised.

\section{Mentor role}

The competencies in the mentor role entail understanding self and others, communicating effectively and developing employees. Mentors are knowledgeable people who guide less experienced employees. Goleman (2000 cited in Quinn et al., 2003) identifies three prominent features of self-awareness - namely, emotional awareness, self-assessment and selfconfidence, all of which are imperative for managerial success. Mentoring relationships open avenues for mentors to develop their interpersonal skills and increase their feelings of selfesteem and worth to the organisation (Noe, Hollenbeck, Gerhart \& Wright, 2008).

Communication, a management competency and responsibility (Daft, 2005; Joseph, Rajendran, Kamalanabhan \& Anantharaman, 1999; Oakland \& Oakland, 2001; Vora, 2004), is important to the mentor role to improve and train people in the main communication tasks (Evans, 2005) and to encourage team participation on company matters (Oakland \& Oakland, 2001). Furthermore, effective delegation is beneficial for managers, the organisation and employees (Cameron \& Whetton, 1983) and is a calculated risk taken by managers with the conviction that staff has the potential to work effectively and efficiently with some training (Winfield, Bishop \& Porter, 2004). As a core element of successful management and leadership (Crainer, 1998, cited in Mullins, 2002) delegation improves productivity, and with authority and responsibility employees strive toward goal accomplishment. Matching tasks to professionally competent people and matching skills to projects create time for managers to improve their skills.

\section{Facilitator role}

The competencies in the facilitator role comprise building teams, using participative decision-making and managing conflict. Work teams may assume managerial activities, such as 'scheduling work' and 'coordinating activities' (Noe et al., 2008, p. 45). Building teams contribute to organisational success and customer satisfaction, transformation and organisational change within an environment whereby people use resources effectively to make continuous improvements (Ozgener, 2003). In line with this thinking, Kern (1997) asserts that team activity aligned with an organisation-wide strategy spells effectiveness.

Participative decision making signifies a mutual understanding of superiors and subordinates. The effectiveness of this 'socially constructed phenomenon' (Harrison, 1985, p. 101) depends on its appropriate 'situational application and proper functioning' (Lengnick-Hall \& Lengnick-Hall, 1992, p. 104). When properly implemented, participative management satisfies the need for autonomy, meaningful work and interpersonal contact (Sashkin, 1984). French, Rayner, Rees and Rumbles (2008, p. 430) emphasise that participative leadership entails 'consulting with employees and seeking and accounting for their suggestions before making decisions'. Also, conflict, managed effectively, can lead to goal accomplishment and serve as the foundation of organisational effectiveness (French et al., 2008). Successful conflict management unites people in adversity, improves communication by allowing them to voice their opinions (Winfield et al., 2004) and thereby enables beneficial outcomes to emerge (Mullins, 2002). Conflict management includes initiating or encouraging conflict to achieve a positive outcome. The expertise in conflict negotiation and resolution allows for employees to 'focus on positive value-creating activities without distraction' (French et al., 2008, p. 544). A conflict-free environment would be one that is so homogeneous that it cannot be innovative or productive.

\section{Monitor role}

The monitor role is associated with the competencies of managing information through critical thinking, managing information overload, and managing core processes (Quinn et al., 2003). Critical thinking entails systematic thinking to consider problem areas for the best decision. Most of a manager's time is spent giving evidence supporting his/her views and evaluating the evidence of others. Critical thinkers 'value and adhere' to intellectual standards (Kelly, 1999) and the real nature of problems are determined using logic and rational decision making (Lister, 2007).

When information exceeds the processing capacity, information overload occurs (Robbins, 2003), which can reduce managerial problem-solving and decision-making. Excess mail and the challenge of channelling and managing information (Quinn et al., 2003) and organising content is an imperative managerial skill. By overcoming the hectic chaos of information overload managers can be more productive. A monitor's task is to ensure the management of information; however, managers need to guard against selecting, ignoring and forgetting information, as lost information may result in less effective communication (Robbins, 2003). In addition, managers should identify core processes and ensure that they do not lose track of outputs due to their demanding managerial activities. The management of core processes, organisational growth and the management of that growth contributes to organisational success. There are activities that achieve outputs, yet with too much focus on activities they become ends in themselves and hence managers 'lose sight of outputs' (Quinn et al., 2003). Managers therefore need to identify core activities, as the quality of those activities contribute to a company's overall success.

\section{Co-ordinator role}

The competencies of managing work flow and projects, designing work and managing across functions (Quinn et al., 2003) shed further light on an organisation's routine work processes. Managing projects is a management tool which requires effective leadership to focus on results and foster an atmosphere for goal accomplishment, among others (Loo, 1996). Effective project management requires the selection of competent people with technical competence, commitment (Davidson, 1987), an efficient goal accomplishment process and proper co-ordination. Skilful project managers rely on people management skills, such as communication and leadership (Bilton, 2007). Also, complex goals can be achieved by integrating multi-functional inputs into a team relationship (Brown, 1999).

When organisations control the design of work processes, work should be simple, standardised and specialised, and supervision and pay incentives should be used to motivate individuals for better task performance (Lawler, 1992 cited 
in Quinn et al., 2003). With detailed knowledge of the tasks performed, a manager has alternative methods to design a job, which can be conducted effectively 'through understanding the trade-offs between certain design approaches' (Noe et al., 2008 , p. 166). Hence, various job design strategies exist and their appropriateness is situational. Furthermore, the challenge of managing across functions is to create 'ad hoc structures' that 'transcend and operate' within an organisational design that is traditional (Quinn et al., 2003, p. 171). Of recent, attention has focused on organisational processes that create cross-functional boundaries, with cross-functional teams being popular (Quinn et al., 2003). These teams comprise specialists from diverse and functional areas within an organisation, who formulate ideas and solve problems in a manner that enables them to perform tasks effectively and timely.

\section{Director role}

The competencies in the director role entail communicating a vision, setting goals and objectives, and designing and organising. Kouzes and Posner (1987, p. 124) consider vision as 'central to leadership effectiveness', with people's involvement being aligned with the vision, thereby committing energies to its realisation. Viewed as a stimulant of the future and a 'noble statement of long-term purpose' (Gitlow, Oppenheim, Oppenheim \& Levine, 2005, p. 549), a vision is needed for an organisational change process. Tushman and Anderson (2004, p. 206) maintain that a well-conceived vision consists of 'core ideology and envisioned future', with the first step being to 'recast your vision or mission into an effective context for building a visionary company'. Spallina (2004) adds that the vision statement needs to be market based, showing leaders an estimation in terms of need and demand.

Goal setting clarifies purpose and provides direction with the focus on goal realisation. An organisation's goals determine inputs and outputs (Mullins, 2002). High-quality goals should suit the mission, be challenging and realistic (Rausch, 1980). Specific, challenging goals show better performance than easily achieved goals, by formulating objectives and setting steps to meet or exceed the objectives, among others (Quinn et al., 2003). This is because clear and specific goals reduce the chances of miscommunication or misunderstanding and provide a clearer aim to achieve. Furthermore, when goals are challenging people are motivated to extend their effort and take more initiative thereby, enhancing performance. An effective goal programme compels a supportive environment from managers, who can make goal targets easier for subordinates to achieve by formulating them collaboratively and making them specific and challenging (Whetton \& Cameron, 2005). In addition, designing and organising are driven by the vision and strategy and since every design has strengths and weaknesses, it allows opportunity for changes and improvements. Academic scholars and practitioners have noticed that changes in work design impact on organisational performance (Sinha \& Van de Ven, 2005).

\section{Producer role}

The competencies in the producer role consist of working productively, fostering a productive work environment and managing time and stress while balancing competing demands. Organisations have associated high productivity with superior performance. Garfield (1986) found peak performers to be results orientated, to value internal goals and rewards and to care about task performance. Motivating employees is the key to high organisational performance as companies are operating in continuously changing markets where competition, innovation and continuous improvements are intense (Cooper, 2003).

With challenges, organisations are entering into a psychological contract with their employees. Effective managers must concern themselves with the productivity of people and work units as productivity is 'a benchmark of managerial and organizational success' (French et al., 2008, p. 18). In this regard, the expectancy theory provides a 'comprehensive process approach' to motivating others. One can adopt three ways to implement the expectancy theory: 'Tie effort to performance. Link performance to outcome(s). Understand valences for desired employee outcomes' (Quinn et al., 2003, p. 236). The rationale is to begin the psychological contract with employees taking cognisance of the importance and value of people as human assets and to provide a challenging work environment, opportunities for development and suitable rewards.'

Progressive organisations recognise the need to support their personnel by adopting strategies that minimise stress and burnout and maximise performance (French et al., 2008). Work overload, time pressures and work conflict, interpersonal work relationships and office politics are largely external influences that can result in stress irrespective of an employee's personality or orientations. Relaxation and time management techniques assist in managing individual stress. In particular, time management techniques need to take cognisance of managers' need for a more 'fluid' approach to time (Deutschman, 1992 cited in Quinn et al., 2003, p. 253) - one that stresses the need to identify priorities and concentrates on the crucial tasks than on outlining each minute of the day.

\section{Broker role}

The core competencies in the broker role are building and maintaining a power base, negotiating agreement and commitment and presenting ideas. Managers obtain power from the organisation (position power) and other people (personal power) (French et al., 2008). Power is often defined as 'the ability to produce; the capacity to mobilize people and resources to get things done' (Kanter, 1983, p. 213). Power, at the organisational level, influences the flow of 'energy and resources' toward goals (Quinn et al., 2003). Managers use power to exercise influence over employees in the work environment (French et al., 2008).

Negotiation is significant in today's work environment as people are becoming involved in decisions regarding their work and themselves (French et al., 2008). The guiding principles are to separate people and problems, focus on interests and gather various possibilities before decisions are taken. Even management is divided on how negotiations should be approached: some may focus on future employee relations while others may consider controlling cost (Noe et al., 2008). When employees are committed to the organisation, there is integration and congruency with organisational and individual goals (Hall, Schneider \& Nygren, 1970). When a new idea is developed, 'idea champions' promote the idea enthusiastically, building support, overcoming any resistance and ensuring implementation of the innovation (Robbins, 2003). Managers are pressured to generate ideas faster as organisations are competing worldwide. Maurer (2002, p. 35) identifies the principles of valuing the relationship with others as much as promoting the idea that is valued, that is, the 'power of paying attention' which will guide the idea to implementation and connect without compromising by allowing others to join in developing ideas.

\section{Innovator role}

The competencies in the innovator role involves creativity and entails living with change, thinking creatively and managing change (Quinn et al., 2003). When living with change, one needs to consider the increasing pressures of change as a result of changing markets, competition, technology and available resources (Winfield et al., 2004). Effective leadership by all leaders in the organisation is needed by most change initiatives (French et al., 2008). New products need to be developed and marketed rapidly, and planned change tries to improve the organisation's ability to adapt to environmental changes (Robbins, 2003). The key is to know the direction that is taken and work towards this higher purpose. 
Creativity includes 'expertise, creative-thinking skills, and intrinsic task motivation' (Amabile, 1997 cited in Robbins, 2003, p. 133). Creative thinking skills include the ability to use analogies for ideas from one context to another (Robbins, 2003) Research has shown the positive relationship between creative problem solving and successful organisations (Sternberg, 1999 cited in Cameron \& Whetton, 2005). Almost all managerial problem solving needs a measure of creativity as managers 'mentally take things apart, rearrange the pieces in new and potentially productive configurations, and look beyond normal frameworks for new solutions' (Kreitner, 2007, p. 232). Creativity requires an effective interplay between knowledge imagination and assessment in order to reconfigure experience (Bilton, 2007).

One approach to change is based on 'process alignment, and starting with the vision and mission statements, analyzing the critical success factors, and moving on to the core processes, is the most effective way to engage the staff in an enduring change process' (Oakland, 2000, p. 244). To take a decision in work processes, procedures or structure, managers need to look at the design of the change, what change should occur and the process of change implementation (Quinn et al., 2003). Managers need to face new realities of competitiveness and they need to know what strategies need to be implemented and how. The philosophy of management development recognises that there are always more things to learn and new ideas that will challenge managers to enhance their abilities (Quinn et al., 2003) and roles/competencies.

\section{Research objectives and hypotheses}

The overall aim of the study is to determine the extent to which managers in the public sector possess the roles/competencies needed to be effective managers and the critical ingredients for their optimal development. Therefore, the objectives of the study are:

- To assess the extent to which the management cadre displays the managerial roles/competencies outlined in the Competing Values Framework (namely, that of mentor facilitator, monitor, co-ordinator, director, producer, broker and innovator) and to identify areas for management development, if any.

- To evaluate whether the managerial roles/competencies outlined in the Competing Values Framework significantly inter-correlate with each other.

- To assess the extent to which the critical managerial roles/ competencies are influenced by biographical variables (managerial level, age, race, tenure, gender).

- To create a framework that highlights areas for developing managerial roles/competencies.

The second and third objectives are respectively evaluated in terms of the following two hypotheses:

Hypothesis 1: There exist significant intercorrelations among the respective managerial roles/competencies (mentor, facilitator, monitor, co-ordinator, director, producer, broker, innovator) needed to manage effectively.

Hypothesis 2: There is a significant difference in the perceptions of managers varying with regard to biographical variables (managerial level, age, race, tenure, gender) regarding the degree to which they possess and display the respective managerial roles/competencies (mentor, facilitator, monitor, co-ordinator, director, producer, broker, innovator) required for managerial effectiveness.

\section{RESEARCH DESIGN}

\section{Research approach}

A cross-sectional (data were collected at one point in time), survey-based study was designed to evaluate the extent to which the management echelon possesses and displays the critical managerial roles/competencies needed to manage effectively and to identify areas, if any, for effective management development.

\section{Research method}

\section{Research participants}

The population consisted of middle, senior and top management in a large public sector department in eThekweni (Durban), South Africa. The population comprised approximately 400 managers. The sample of 202 subjects was drawn using a stratified random sampling technique to ensure proportionate representation from the stratum of the designated group of interest, that is, managerial level defined in terms of middle, senior and top managers. In terms of the composition, $19.8 \%$ of the sample consisted of top managers, $41.9 \%$ were senior managers and $38.4 \%$ were middle managers. In addition, $43 \%$ of the respondents were 50 years and older, $40.7 \%$ were between 40 and 49 years, and $14 \%$ were between 30 and 39 years, while only $2.3 \%$ were younger than 30 years. White respondents made up $41.9 \%$ of the sample, followed by Indians (32.6\%), Blacks (22.1\%) and Coloureds (3.4\%). In terms of tenure, 38.4\% of the respondents worked in the organisation for 21 years or more, an equal percentage (17.4\%) served for 11-15 and 16-20 years, $16.3 \%$ served for a term of $6-10$ years and only $10.5 \%$ worked in the company for five years or less. The majority of the subjects were male $(83.7 \%)$, while only $16.3 \%$ were female which indicates the disproportionate percentage of female to male employees in management.

The adequacy of the sample was determined using the Kaiser-Meyer-Olkin measure of sampling adequacy (0.768) and the Bartlett's test of sphericity (2975.330, $p=0.000$ ), which respectively indicated suitability and significance. The results indicated that the preconditions of normality and homoscedasticity were satisfied.

\section{Measuring instrument}

Data were collected using a self-developed, self-administered, precoded questionnaire consisting of two sections relating to biographical information and to the managerial roles needed to create effective managers as outlined in the Competing Values Framework. The biographical data (managerial level, age, race, tenure, gender) were collected using a nominal scale with precoded option categories. The 40 items assessing the managerial roles were measured using a five-point Likert scale ranging from, (1) strongly disagree, (2) disagree, (3) neither agree nor disagree, (4) agree and (5) strongly agree. The questionnaire was formulated on the basis of identifying recurring themes that surfaced during the literature review as well as the competencies outlined in the Competing Values Framework. Hence, items included in the questionnaire related directly to the constructs being measured, namely the mentor, facilitator, monitor, co-ordinator, director, producer, broker and innovator roles of management, each of which comprised five items. This ensured face and content validity. For example, the mentor role consisted of five items relating to understanding of self and others, communicating effectively and developing employees.

The validity of the questionnaire was assessed using factor analysis. A principal component analysis was used to extract initial factors and an iterated principal factor analysis was performed using the Statistical Package for the Social Sciences (SPSS) with an orthogonal varimax rotation. Only item loadings $>0.4$ were considered to be significant and if an item loaded significantly on more than one factor, only that with the highest loading was considered. In terms of the validity of the items measuring managerial roles and competencies, the eight roles outlined in the Competing Values Framework (mentor, facilitator, monitor, co-ordinator, director, producer, broker and innovator) were generated with all factors depicting roles having eigenvalues greater than unity (see Table 1). 
TABLE 1

The validity of the measuring instrument measuring managerial roles

\begin{tabular}{lll}
\hline Factor & Eigenvalue & \% of total variance \\
\hline 1 & 4.52 & 11.03 \\
2 & 3.10 & 7.56 \\
3 & 2.69 & 6.55 \\
4 & 2.46 & 6.00 \\
5 & 2.42 & 5.90 \\
6 & 2.26 & 5.51 \\
7 & 2.12 & 5.18 \\
8 & 1.90 & 4.64 \\
\hline
\end{tabular}

The items were also reflected as having a very high level of internal consistency and reliability, with the Cronbach's coefficient alpha being 0.893 .

\section{Research procedure}

After permission to undertake the study was received, inhouse pretesting was adopted to assess the suitability of the instrument. Pilot testing was also carried out using eight subjects, who were selected using the same procedures and protocols adopted for the larger sample. The feedback from the pilot testing confirmed that the questionnaire was appropriate in terms of relevance and construction and adhered to the principles of wording and measurement. The questionnaires were then administered in conjunction with two staff members in the Skills Development Department in the target organisation and managers could either respond by posting back the questionnaire in the attached self-addressed envelope or returning it to the researcher electronically. Data were collected over a three-month period.

\section{Statistical analysis}

Data obtained from the questionnaires were captured using Microsoft Excel (Version 5), processed using Simstat and analysed using descriptive (means, standard deviations) and inferential (correlation, ANOVA, Scheffe post-hoc test, $t$-test) statistics. Results were considered to be significant at at least the $5 \%$ level of significance.

\section{RESULTS}

\section{Assessment of competencies needed}

To determine the extent to which managers possess the competencies and fulfil the roles necessary to manage effectively, the eight roles defined in the Competing Values Framework were evaluated using the five-point Likert scale. The higher the mean score value, the greater the extent to which the managers possess and fulfil the specified role (see Table 2).

Table 2 indicates that managers in this public sector department are good at monitoring $($ mean $=3.80)$ and mentoring $($ mean $=$ 3.66). However, Table 2 also indicates deficiencies in fulfilling the roles of director $($ mean $=3.28)$ and facilitator $($ mean $=3.26$ ).
The managerial roles, in descending level of fulfilment, are presented below. The mean score values against a maximum attainable score of 5 indicate that there is still room for improvement in every one of the managerial roles. Frequency analyses in each of the managerial roles (see Table 3) reflect specific deficiencies and areas for development:

\section{Monitor role}

- $33.1 \%$ of the respondents believe that managers in the public sector department do not strive to translate the overload of data into valuable information.

- $29.2 \%$ of the managers are not convinced that managers in the organisation are able to effectively operate and control core processes.

\section{Mentor role}

- $14.4 \%$ of the managers are not convinced that employees' competencies are developed by delegating more responsibilities to them and by providing feedback to them.

- $29.7 \%$ of the respondents felt that managers do not continuously ask for feedback about themselves to increase the probability of openness and learning on the part of others.

\section{Innovator role}

- $21.8 \%$ of the managers believe that routine in their organisation shifts their focus away from possible outcomes.

\section{Broker role}

- $23.8 \%$ of the managers disagreed or strongly disagreed that most decisions in their organisation are reached through negotiations.

- $39 \%$ of the respondents were not convinced that managers recognise that the three levels of power (organisational, group, individual) are ultimately directed towards goal attainment.

- $42 \%$ of the managers were not convinced that idea presentation is a management communication task in their organisation.

\section{Co-ordinator role}

- $35.1 \%$ of the managers are not convinced that all project managers are able to undertake activities effectively across functional areas.

- $43.6 \%$ of the managers did not believe that cross-functional teams were effective enough to enable them to respond quickly to competitive changes in the environment.

\section{Producer role}

- $20.3 \%$ of the managers do not agree that individuals in the organisation work productively to foster a productive work environment.

- $21.8 \%$ of the managers are not convinced that their organisation strives to optimise time management and minimise stress management.

TABLE 2

Descriptive statistics - managerial roles/competencies needed to be effective managers

\begin{tabular}{|c|c|c|c|c|c|c|c|c|}
\hline \multirow[t]{2}{*}{ Role } & \multirow[t]{2}{*}{ Mean } & \multirow[t]{2}{*}{$\%$ role* $^{*}$} & \multirow[t]{2}{*}{ Variance } & \multirow[t]{2}{*}{ s.d. } & \multirow[t]{2}{*}{ Min } & \multirow[t]{2}{*}{ Max } & \multicolumn{2}{|c|}{ Confidence Interval } \\
\hline & & & & & & & Lower & Upper \\
\hline Mentor & 3.66 & 73.2 & 0.326 & 0.571 & 1 & 5 & 3.52 & 3.72 \\
\hline Facilitator & 3.26 & 65.2 & 0.439 & 0.662 & 1 & 5 & 3.59 & 3.94 \\
\hline Monitor & 3.80 & 76 & 0.334 & 0.578 & 2 & 5 & 3.62 & 3.80 \\
\hline Co-ordinator & 3.55 & 71 & 0.397 & 0.630 & 1 & 5 & 3.54 & 3.75 \\
\hline Director & 3.28 & 65.6 & 0.496 & 0.704 & 1 & 5 & 3.26 & 3.53 \\
\hline Producer & 3.40 & 68 & 0.406 & 0.637 & 1 & 5 & 3.20 & 3.47 \\
\hline Broker & 3.61 & 72.2 & 0.306 & 0.554 & 1 & 5 & 3.49 & 3.71 \\
\hline Innovator & 3.63 & 72.6 & 0.266 & 0.516 & 2 & 5 & 3.61 & 3.77 \\
\hline
\end{tabular}

s.d. = standard deviation

${ }^{*}$ percentage to which managerial role is being fulfilled. 
TABLE 3

Areas for development in each managerial role and percent of negative perceptions regarding each skill

\begin{tabular}{|c|c|c|}
\hline Role & Areas for development in each role & $\%$ respondents* \\
\hline \multirow[t]{2}{*}{ Monitor } & Managers in the organisation cannot effectively operate and control core processes. & 29.2 \\
\hline & Managers do not strive to translate the overload of data into valuable information. & 33.1 \\
\hline Mentor & In their department, employee competencies are not developed by delegating more responsibilities to them and providing feedback to them. & 14.4 \\
\hline Innovator & The routine in the department shifts the focus of managers away from possible outcomes. & 21.8 \\
\hline \multirow[t]{3}{*}{ Broker } & Most decisions in the organisation do not take place through negotiations. & 23.8 \\
\hline & Managers do not recognise that all the three levels of power (organisational, group, individual) are ultimately directed towards goal attainment. & 39 \\
\hline & Idea presentation is not a management communication task in the organisation. & 42 \\
\hline \multirow[t]{2}{*}{ Coordinator } & Managers do not effectively utilise cross-functional teams to respond quickly to competitive changes in the environment. & 43.6 \\
\hline & Project managers are not able to undertake activities effectively across functional areas. & 35.1 \\
\hline \multirow[t]{2}{*}{ Producer } & Individuals do not work productively to foster a productive work environment. & 20.3 \\
\hline & The organisation does not strive to optimise time management and minimise stress management. & 21.8 \\
\hline \multirow[t]{2}{*}{ Director } & Managers do not constantly communicate and operationalise the overall picture and vision of the organisation. & 35 \\
\hline & Every effort is not made to translate organisational goals into sub-goals at various levels of the organisation. & 15.9 \\
\hline \multirow[t]{4}{*}{ Facilitator } & Participatory decision-making is not practiced so that employees have a say in decisions that affect them. & 19.8 \\
\hline & The organisation does not provide an effective team-building environment that values opinions and open resolution of conflict. & 21.8 \\
\hline & Conflict is not effectively managed in the organisation to increase positive outcomes. & 19.9 \\
\hline & More collaborative approaches to conflict management are needed for effectiveness in the long run. & 49 \\
\hline
\end{tabular}

*percentage respondents with negative perception

\section{Director role}

- $15.9 \%$ of the managers disagreed or strongly disagreed that every effort is made to translate organisational goals into sub-goals at various levels of the organisation.

- $35 \%$ of the respondents do not believe that managers constantly communicate and operationalise the vision of the organisation.

\section{Facilitator role}

- $21.8 \%$ of the managers believe that their organisation does not provide an effective team-building environment that values various opinions and open resolution of conflict.

- $19.9 \%$ of the managers either disagreed or strongly disagreed that conflict is effectively managed in their organisation to increase positive outcomes.

- $49 \%$ of the managers in this study believe that more collaborative approaches to conflict are needed for effectiveness in the long term.

The roles influencing managerial effectiveness were intercorrelated to assess whether they relate to each other, thereby testing hypothesis 1 (see Table 4).

Table 4 indicates that there exists significant intercorrelations among the sub-dimensions determining the effectiveness of managerial roles/competencies (mentor, facilitator, monitor, co-ordinator, director, producer, broker, innovator) at the $1 \%$ level of significance. Hence, hypothesis 1 may be accepted. The significant inter-correlations among the managerial roles emphasise that the competencies within one role overlaps with those in each other role. Higher degrees of overlap or intercorrelation exist between the producer role and the facilitator, monitor and director roles. Furthermore, high degrees of overlap were evident between the monitor, mentor and facilitator roles. Since the roles overlap, the implication is that any improvement in one of these managerial roles has the potential to have a ripple effect thereby enhancing managerial effectiveness to a greater extent.

In order to test hypothesis 2, ANOVA was conducted to assess whether managers varying in biographical variables (managerial level, age, race, tenure, gender) differ significantly in the degree to which they possess and display the various managerial roles needed for managerial effectiveness. Furthermore, in order to determine where significant differences lie in this regard, the Post-Hoc Scheffe's Test was used.

Table 5 indicates that managers in the different levels of management (middle, senior and top) significantly differ in the extent to which they possess and display the director competencies at the $1 \%$ level of significance. In order to determine exactly where these differences lie, a Scheffe posthoc test was conducted. The results indicate that top managers $($ mean $=3.68)$ possess and display significantly higher levels of director competencies than senior $($ mean $=3.25)$ and middle (mean $=3.20)$ managers

Table 5 also indicates that no other significant differences exist among the managers from the different levels of management regarding the mentor, facilitator, monitor, co-ordinator, producer, broker and innovator roles. Hence, hypothesis 2 may only be accepted partially in terms of managerial level differences.

Table 6 indicates that there is a significant difference in the extent to which managers from the different age groups possess and display facilitator and the broker competencies, at the 5\% and the $1 \%$ level of significance respectively. In order to assess exactly where these differences lie, a Scheffe post-hoc test was conducted. With regard to the facilitator role, it was noted that managers who are $20-29$ years of age (mean $=3.68$ ) differ significantly from managers who are $40-49$ years of age (mean $=3.27$ ) and to a large extent from managers who are 50 years and older (mean $=3.10$ ). This implies that managers who are 20 29 years of age facilitate collective efforts and manage conflict to a greater extent than managers who are 40 years of age and older. Hence, younger managers are more convinced that managers in the organisation are fulfilling the facilitator role. This perception diminishes with older managers. In addition, with regard to the broker role, managers who are 30-39 years of age (mean $=3.69)$ and $40-49$ years of age $($ mean $=3.72)$ differ significantly from managers who are 50 years and older (mean $=3.42$ ). This significant difference reflects that managers who are 30-49 years of age fulfil the broker role to a greater extent than managers who are 50 years and older. Hence, managers 
TABLE 4

Intercorrelations - managerial roles/competencies

\begin{tabular}{|c|c|c|c|c|c|c|c|c|c|}
\hline Role & & Mentor & Facilitator & Monitor & Coordinator & Director & Producer & Broker & Innovator \\
\hline Mentor & $\begin{array}{l}r \\
p\end{array}$ & 1 & & & & & & & \\
\hline Facilitator & $\begin{array}{l}r \\
p\end{array}$ & $\begin{array}{l}0.54 \\
0.000^{*}\end{array}$ & 1 & & & & & & \\
\hline Monitor & $\begin{array}{l}r \\
p\end{array}$ & $\begin{array}{l}0.58 \\
0.000^{*}\end{array}$ & $\begin{array}{l}0.58 \\
0.000^{*}\end{array}$ & 1 & & & & & \\
\hline Coordinator & $\begin{array}{l}r \\
p\end{array}$ & $\begin{array}{l}0.48 \\
0.000^{*}\end{array}$ & $\begin{array}{l}0.41 \\
0.000^{*}\end{array}$ & $\begin{array}{l}0.54 \\
0.000^{*}\end{array}$ & 1 & & & & \\
\hline Director & $\begin{array}{l}r \\
p\end{array}$ & $\begin{array}{l}0.51 \\
0.000^{*}\end{array}$ & $\begin{array}{l}0.47 \\
0.000^{*}\end{array}$ & $\begin{array}{l}0.51 \\
0.000^{*}\end{array}$ & $\begin{array}{l}0.44 \\
0.000^{*}\end{array}$ & 1 & & & \\
\hline Producer & $\begin{array}{l}r \\
p\end{array}$ & $\begin{array}{l}0.46 \\
0.000^{*}\end{array}$ & $\begin{array}{l}0.60 \\
0.000^{*}\end{array}$ & $\begin{array}{l}0.58 \\
0.000^{*}\end{array}$ & $\begin{array}{l}0.38 \\
0.000^{*}\end{array}$ & $\begin{array}{l}0.56 \\
0.000^{*}\end{array}$ & 1 & & \\
\hline Broker & $\begin{array}{l}r \\
p\end{array}$ & $\begin{array}{l}0.49 \\
0.000^{\star}\end{array}$ & $\begin{array}{l}0.47 \\
0.000^{\star}\end{array}$ & $\begin{array}{l}0.45 \\
0.000^{\star}\end{array}$ & $\begin{array}{l}0.41 \\
0.000^{*}\end{array}$ & $\begin{array}{l}0.39 \\
0.000^{*}\end{array}$ & $\begin{array}{l}0.40 \\
0.000^{*}\end{array}$ & 1 & \\
\hline Innovator & $\begin{array}{l}r \\
p\end{array}$ & $\begin{array}{l}0.48 \\
0.000^{*}\end{array}$ & $\begin{array}{l}0.3 \\
0.000^{*}\end{array}$ & $\begin{array}{l}0.40 \\
0.000^{*}\end{array}$ & $\begin{array}{l}0.32 \\
0.000^{*}\end{array}$ & $\begin{array}{l}0.34 \\
0.000^{*}\end{array}$ & $\begin{array}{l}0.31 \\
0.000^{*}\end{array}$ & $\begin{array}{l}0.44 \\
0.000^{*}\end{array}$ & 1 \\
\hline
\end{tabular}

TABLE 5

ANOVA and Post-Hoc Scheffe's test - managerial level

\begin{tabular}{|c|c|c|c|c|c|}
\hline \multirow[t]{2}{*}{ Managerial role } & \multicolumn{2}{|c|}{ ANOVA } & \multicolumn{3}{|c|}{ Post-Hoc Scheffe's Test } \\
\hline & $F$ & $p$ & Sub-groups of level of management & Mean & s.d. \\
\hline Mentor & 0.787 & 0.457 & - & - & - \\
\hline Facilitator & 0.640 & 0.528 & - & - & - \\
\hline Monitor & 2.493 & 0.085 & - & - & - \\
\hline Co-ordinator & 2.743 & 0.067 & - & - & - \\
\hline \multirow[t]{3}{*}{ Director } & 5.115 & $0.007^{*}$ & Top Manager & 3.68 & 0.596 \\
\hline & & & Senior Manager & 3.25 & 0.648 \\
\hline & & & Middle Manager & 3.20 & 0.730 \\
\hline Producer & 1.019 & 0.363 & - & - & - \\
\hline Broker & 1.209 & 0.301 & - & - & - \\
\hline Innovator & 0.180 & 0.836 & - & - & - \\
\hline
\end{tabular}

${ }^{*} p<0.01$

s.d. = standard deviation

TABLE 6

ANOVA and Post-Hoc Scheffe's test - Age

\begin{tabular}{|c|c|c|c|c|c|}
\hline \multirow[t]{2}{*}{ Managerial role } & \multicolumn{2}{|c|}{ ANOVA } & \multicolumn{3}{|c|}{ Post-Hoc Scheffe's Test } \\
\hline & $F$ & $p$ & Sub-groups of age in years & Mean & s.d. \\
\hline Mentor & 0.993 & 0.397 & - & - & - \\
\hline \multirow[t]{4}{*}{ Facilitator } & 2.809 & $0.041^{* *}$ & $20-29$ & 3.68 & 0.431 \\
\hline & & & $30-39$ & 3.32 & 0.513 \\
\hline & & & $40-49$ & 3.27 & 0.706 \\
\hline & & & $50+$ & 3.10 & 0.718 \\
\hline Monitor & 1.137 & 0.335 & - & - & - \\
\hline Co-ordinator & 1.255 & 0.292 & - & - & - \\
\hline Director & 0.581 & 0.628 & - & - & - \\
\hline Producer & 2.509 & 0.060 & - & - & - \\
\hline \multirow[t]{4}{*}{ Broker } & 4.183 & $0.007^{*}$ & $20-29$ & 3.49 & 0.259 \\
\hline & & & $30-39$ & 3.69 & 0.450 \\
\hline & & & $40-49$ & 3.72 & 0.592 \\
\hline & & & $50+$ & 3.42 & 0.578 \\
\hline Innovator & 2.207 & 0.089 & - & - & - \\
\hline
\end{tabular}

${ }^{*} p<0.01,{ }^{* \star} p<0.05$

$p<0.01, \quad p<0.05$
s.d. = standard deviation

between the ages of 30 and 49 have a more positive view of managers in the organisation fulfilling the broker role than other managers. In particular, managers who are 40-49 years of age build morale and balance the needs of individuals and groups to a much greater extent than managers who are 50 years and older.

Table 6 also indicates that no other significant differences exist among the managers varying in age regarding the mentor, monitor, co-ordinator, director, producer and innovator roles. Hence, hypothesis 2 may only be accepted partially in terms of differences based on age.
Table 7 indicates that there is a significant difference in the extent to which managers varying in race possess and display the co-ordinator competencies needed to manage effectively, at the $1 \%$ level of significance. In order to determine exactly where these differences lie, a Scheffe post-hoc test was conducted. The results indicate that Indian managers $($ mean $=3.77)$ differ significantly from Black (mean $=3.44)$, White $($ mean $=3.42)$, and Coloured managers $($ mean $=3.42)$ in terms of the co-ordinator role. The significant differences imply that Indian managers are more convinced than Black, White and Coloured managers that they are fulfilling their co-ordinator roles in the organisation. 
TABLE 7

ANOVA and Post-Hoc Scheffe's test - Race

\begin{tabular}{|c|c|c|c|c|c|}
\hline \multirow[t]{2}{*}{ Managerial role } & \multicolumn{2}{|c|}{ ANOVA } & \multicolumn{3}{|c|}{ Post-Hoc Scheffe's Test } \\
\hline & $F$ & $p$ & Sub-groups of Race & Mean & s.d. \\
\hline Mentor & 1.382 & 0.249 & - & - & - \\
\hline Facilitator & 1.716 & 0.165 & - & - & - \\
\hline Monitor & 1.903 & 0.130 & - & - & - \\
\hline \multirow[t]{4}{*}{ Co-ordinator } & 4.778 & $0.003^{*}$ & Indian & 3.77 & 0.566 \\
\hline & & & Black & 3.44 & 0.669 \\
\hline & & & Coloured & 3.42 & 0.568 \\
\hline & & & White & 3.42 & 0.639 \\
\hline Director & 0.198 & 0.898 & - & - & - \\
\hline Producer & 1.840 & 0.141 & - & - & - \\
\hline Broker & 2.558 & 0.056 & - & - & - \\
\hline Innovator & 1.621 & 0.186 & - & - & - \\
\hline
\end{tabular}

${ }^{*} p<0.01$

s.d. $=$ standard deviation

Table 7 also indicates that no other significant differences exist among the managers varying in race regarding the mentor, facilitator, monitor, director, producer, broker and innovator roles. Hence, hypothesis 2 may only be accepted partially in terms of race differences.

Contrary to belief, Table 8 indicates that there is no significant difference in the extent to which managers varying in tenure possess and display the managerial competencies needed to manage effectively. Hence, hypothesis 2 may not be accepted in terms of differences based on tenure.

Table 9 indicates that there is no significant difference in the extent to which male and female managers possess and display the managerial competencies needed to manage effectively. Hence, hypothesis 2 may not be accepted in terms of gender differences.

\section{DISCUSSION}

The objective of this study was to assess the extent to which the management cadre displays the managerial roles/competencies outlined in the Competing Values Framework (mentor, facilitator, monitor, co-ordinator, director, producer, broker and innovator) and to identify areas for management development if any. This study provides not only an outline of the various managerial skills that need to be developed in order to enhance the managerial performance in each role/competency but also a sound basis for developing the management cadre in the organisation, as effective leadership is pivotal to organisational survival, particularly during the current global economic crisis.

\section{Summary of findings}

The results indicate that the current managers possess and display only an acceptable level of the managerial competencies and in varying degrees: the roles of monitor and mentor are their most dominant leadership roles while those of producer, director and facilitator require the greatest degree of development. As Belasen and Frank (2008) emphasise, leaders face paradoxical tensions and have to utilise multiple and contradictory roles diplomatically when responding to

TABLE 8

ANOVA - Tenture

\begin{tabular}{lll}
\hline Managerial role & $\boldsymbol{F}$ & $\boldsymbol{p}$ \\
\hline Mentor & 0.512 & 0.727 \\
Facilitator & 0.918 & 0.458 \\
Monitor & 0.795 & 0.532 \\
Co-ordinator & 0.935 & 0.448 \\
Director & 0.213 & 0.931 \\
Producer & 1.066 & 0.379 \\
Broker & 0.850 & 0.497 \\
Innovator & 0.816 & 0.519 \\
\hline
\end{tabular}

TABLE 9

$\mathrm{t}$-test - gender

\begin{tabular}{lccc}
\hline Managerial role & \multicolumn{3}{c}{ t-test for equality of means } \\
\cline { 2 - 4 } & $\boldsymbol{t}$ & $\boldsymbol{D} \boldsymbol{f}$ & $\boldsymbol{p}$ \\
\hline Mentor & -0.568 & 197 & 0.123 \\
Facilitator & 0.126 & 196 & 0.900 \\
Monitor & -1.079 & 195 & 0.282 \\
Co-ordinator & -0.865 & 195 & 0.388 \\
Director & -1.046 & 196 & 0.297 \\
Producer & -0.195 & 196 & 0.856 \\
Broker & -0.674 & 195 & 0.501 \\
Innovator & -1.518 & 196 & 0.131 \\
\hline
\end{tabular}

competing demands. Evidently, these public sector managers are displaying the potential to utilise these competing leadership roles in such a manner that the organisation is not dysfunctional; however, they are not performing optimally in each of these roles.

The results also indicate that the eight managerial roles (mentor facilitator, monitor, co-ordinator, director, producer, broker, innovator) significantly intercorrelate with each other. Since the managerial roles overlap significantly (some to a greater extent than others), the implication is that any improvement in these managerial roles has the potential to have a ripple effect, resulting in enhanced managerial competencies, management development and overall managerial effectiveness and comprehensively assessing organisational effectiveness. Therefore, although the model is called the Competing Values Framework because the various roles may be seen to be in conflict, they are, as Quinn et al. (2003) specify, not mutually exclusive. Quinn et al. (2003) emphasise the complementary nature of the eight roles and the fact that it is imperative to integrate the diverse competencies. The significant intercorrelations among the eight roles stress the need for leaders to be ambidextrous in a figurative sense and be able to meet the behaviourally complex challenges in the organisational world. The interconnectedness of the roles, even though they may be perceived as contradictory, emphasise that effective managerial leaders must possess and demonstrate an interplay of all eight roles. However, the strength or magnitude of the interrelationships would indicate that the managers are not effectively displaying paradoxical capabilities, which according to Hart and Quinn (1993) are imperative for managerial effectiveness. This reflects potential areas for management development. For example, the weaker relationship between the director and monitor roles indicates that managers may be decisive yet they may not be able to reflect or that they may have broad vision yet may not be able to pay attention to detail. Some relationships, while being significant, are not strong enough for managers to possess optimum paradoxical capabilities. For example, the relationship between the producer and facilitator roles and the co-ordinator and broker roles may be enhanced 
so that managers can simultaneously and optimally balance both the performance and people orientations. Furthermore, the innovator and monitor roles may be enhanced so that managers can take bold moves as well as be capable of making incremental adjustments. According to Quinn (1988), effective managers have the potential to play multiple and even contradictory leadership roles and those who are effective in all roles are master managers who use behaviour within the correct context. Evidently, the public sector managers in this study need development in this regard; they need to be skilled in effectively utilising competing leadership roles, being ambidextrous and displaying what Denison, Hooijberg and Quinn (1995) refer to as behavioural complexity.

The results indicate the extent to which the critical managerial roles/competencies are influenced by biographical variables (managerial level, age, race, tenure, gender). Managers varying in the biographical variables of managerial level, age and race differ significantly in the extent to which they possess and display various managerial competencies. The results indicate that top managers possess and display significantly higher levels of the director competencies than middle and senior managers, as can be expected. However, the mean score values reflect that overall there is tremendous need for improvement in the extent to which the director role is being fulfilled by the managers. Similarly, Smale and Frisby (1990) noted significant differences in perceived proficiency in several managerial competency areas among employees from different levels of management.

Furthermore, it was found in this study that managers between 20 and 29 years of age possessed and displayed higher levels of the facilitator competencies than all other managers and those between 40 and 49 years of age possessed and displayed more of the broker competencies than all other managers. This indicates that managers between 40 and 49 years of age are better able to build and maintain a power base, negotiate agreement and commitment and present ideas. Furthermore, it was found that managers varying in race differed regarding the co-ordinator role, as Indian managers displayed higher levels of the co-ordinator competencies than all other race groups. Likewise, Goldstein, Yusko and Nicolopoulos (2001) found that managerial competencies varied between Black and White race groups, which was largely attributed to cognitive ability. Contrary to expectations, tenure and gender did not influence any of the eight managerial roles/competencies needed for effective management. Similarly, according to Strebler, Thompson and Heron (1997), related research on gender differences in managerial work indicates that female and male managers do not differ significantly in the competencies they possess. However, Daley and Naff (1998) noted slight differences in the way female and male supervisors perceive the essential responsibilities of the managerial job. Similarly, McGregor and Tweed (2001) noted significant differences between men and women in relation to specific managerial competencies. They found that women displayed a stronger orientation towards dealing with detail, managing budgets and scanning the environment than men.

As a result of the quantitative analyses undertaken, this study has generated a framework that highlights areas for developing the managerial roles of managers in this public sector division by highlighting roles currently being displayed by the management cadre and identifying areas for improvement. Figure 1 depicts the extent to which the managerial roles are being fulfilled by managers in this public sector department. The monitor role lies at the innermost part of the figure, indicating the greatest fulfilment of this role in terms of managerial effectiveness. Based on the mean score values, the facilitator role lies in the outermost segment as managers possess and display these competencies to the least extent. This area reflects the greatest need for improvement in their development towards managerial effectiveness. Hence, as one moves from the innermost segment to the outermost segment, the need for improvement and managerial development for

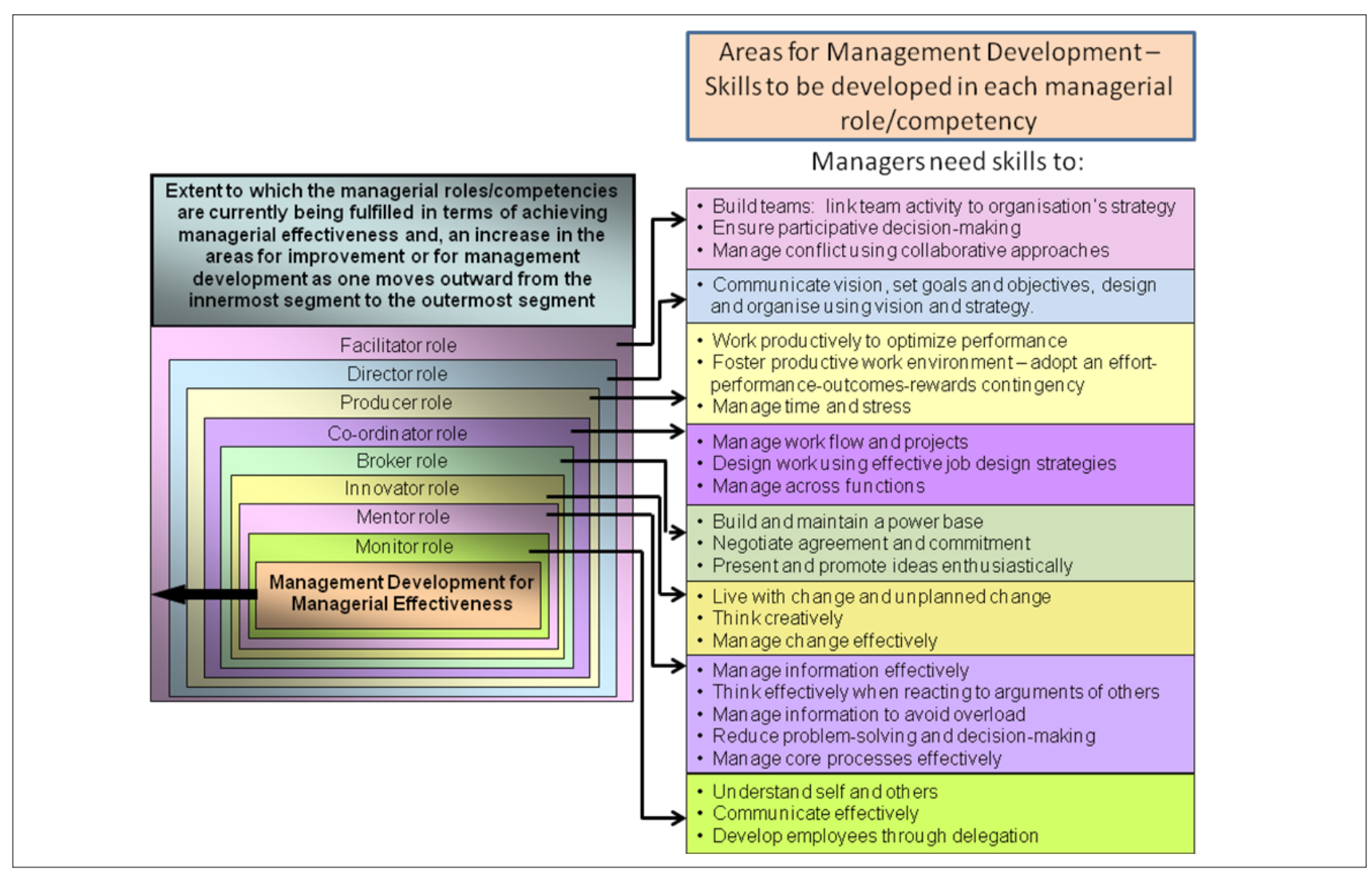

FIGURE 1

The current fulfilment of managerial roles/competencies and, skills or areas for management development to enhance these roles/competencies 
attaining managerial effectiveness in each of the managerial roles/competencies increases, as indicated by the black arrow.

Based on these results and the work of Quinn et al. (2003), proposed recommendations are reflected in Figure 1. These recommendations or areas for management development elucidate the skills that managers need in order to enhance each of the managerial roles, thereby ensuring effective management development, much needed in today's dynamic organisations.

\section{Managerial implications}

As organisations face an increasing number of challenges, their future depends largely on increasing organisational performance, increasing market share and gaining a competitive advantage. One way to accomplish this is to let the management cadre drive all strategies aimed at goal accomplishment. This means that management development is an effective vehicle for organisational effectiveness. This study indicates that while the management cadre in the relevant public sector division are undertaking the various leadership roles/competencies and are attempting to balance the competing demands so as to prevent the organisation from being dysfunctional, they are not doing so optimally. Furthermore, they are not effectively coping with paradoxical tensions and need to develop paradoxical capabilities, become ambidextrous and develop behavioural complexity so that they are able to use the appropriate behaviour within the correct context. Strong empirical support for these findings is provided and recommendations for effective management development are presented graphically.

\section{Limitations of the study}

The sample represents only one public sector department and therefore prevents the generalisability of the results to other public sector institutions and the private sector. Furthermore, in the current research design data were collected using a self-developed, closed-ended questionnaire. In order to probe into managerial practices and identify areas for development, collecting qualitative data via interviews may be more useful, especially if 360 degree feedback on managerial roles/ competencies is obtained.

\section{Suggestions for future research}

This study focused on the extent to which the current management cadre is fulfilling the managerial competencies needed for achieving managerial effectiveness and hence, identifying the areas for management development. Since being ambidextrous and being able to display optimum levels of behavioural complexity is the cornerstone of managerial effectiveness, future research should assess the areas in which managers in the public and private sectors are adopting competing leadership roles as well as areas in which they fall short, thereby identifying areas for developing paradoxical capabilities and reducing paradoxical tensions.

\section{REFERENCES}

Belasen, A., \& Frank, N. (2008). Competing values leadership: Quadrant roles and personality traits. Leadership and Organization Development Journal, 29(2), 127-143.

Bilton, C. (2007). Management and creativity: From creative industries to creative management. Oxford: Blackwell.

Brown, C.J. (1999). Towards a strategy for project management implementation. South African Journal of Business Management, 30(2), 33-38

Cameron, K.S., \& Whetton, D.A. (1983). Organisational effectiveness: One model or several. In Organisational effectiveness: A comparison of multiple models (pp. 1-24). San Diego: Academic Press.
Cooper, D.J. (2003). Leadership for follower commitment. Oxford: Butterworth-Heinemann.

Davidson, J. (1987). Managing projects in organizations: How to make the best use of time, techniques, and people. San Francisco: Jossey-Bass.

Daft, R.L. (2005). The leadership experience. Mason: Thomson South-Western.

Daley, D.M., \& Naff, K.C. (1998). Gender differences and managerial competencies. Review of Public Personnel Administration, 18(2), 41-56.

Denison, D., Hooijberg, R., \& Quinn, R.E. (1995). Paradox and performance: Toward a theory of behavioural complexity in managerial leadership. Organisational Science, 6, 524540.

Evans, J.R. (2005). Total quality: Management, organization, and strategy. (4th edn.). Cincinnati: Thomson SouthWestern.

French, R., Rayner, C., Rees, G., \& Rumbles, S. (2008). Organizational behaviour. Chichester: John Wiley.

Garfield, C.S. (1986). Peak performers. New York: Avon Books.

Gitlow, H.S., Oppenheim, A.J., Oppenheim, R., \& Levine, D.M. (2005). Quality management. (3rd edn.). Boston: McGrawHill.

Goldstein, H.W., Yosko, K.P., \& Nicolopoulos, V. (2001). Exploring Black-White subgroup differences of managerial competencies. Personnel Psychology, 54(January), 78807.

Gómez-Mejía, L.R., Balkin, D.B., \& Cardy, R.L. (2004). Managing human resources. (4th edn.). New Jersey: Prentice Hall.

Hall, D.T., Schneider, B., \& Nygren, N.T. (1970). Personal factors in organizational identification. Administrative Science Quarterly, 15(2), 176-190.

Harrison, T.M. (1985). Communication and participative decision making: An exploratory study. Personnel Psychology, 38(1), 93-116.

Hart, S., \& Quinn, R.E. (1993). Roles executives play: CEOs behavioral complexity and firm performance. Human Relations, 46 (5), 543-574

Joseph, I.N., Rajendran, C., Kamalanabhan, T.J., \& Anantharaman, R.N. (1999). Organizational factors and total quality management - an empirical study. International Journal of Production Research, 37(6), 1337-1352.

Kanter, R.M. (1983). The change masters: Innovation for productivity in the American corporation. New York: Simon \& Shuster.

Kelly, T.A. (1999). Critical thinking for case managers. Inside Case Management, 6(5), 10-12.

Kern, A. (1997, n.d. May). No team is an island. Quality Progress, pp. 110-113.

Kreitner, R. (2007). Management. (10th edn.). Boston: Houghton Mifflin.

Kouzes, J.M., \& Posner, B.Z. (1987). The leadership challenge: How to get extraordinary things done in organizations. San Francisco: Josey-Bass.

Lengnick-Hall, M.L., \& Lengnick-Hall, C.A. (1992). Effective participative decision making: A joint responsibility for success. Employee Responsibilities and Rights Journal, 5(2), $102-116$

Lister, G. (2007). Does your board think critically? American School Board Journal, pp. 42-43.

Loo, R. (1996). Training in project management: A powerful tool for improving individual and team performance. Team Performance Management, 2(3), 6-14.

Maurer, R. (2002, January). Creating a shift. The Journal for Quality E Participation, pp. 35.

McGregor, J., \& Tweed, D. (2001). Gender and managerial competence: support for theories of androgyny? Women in Management Review, 16(6), 279-287.

Meyer, M., Bushney, M., Katz, M., Knoke, G., Lategan, A, Ludike, J., et al. (2007). Managing human resource development: An outcome based approach. (3rd edn.). Cape Town: LexisNexis.

Mullins, L.J. (2002). Management and organisational behaviour. (6th edn.). London: Prentice Hall. 
Noe, R.A., Hollenbeck, J.R., Gerhart, B., \& Wright, P.M. (2008). Human resource management: Gaining a competitive advantage. (6th edn.). Boston: McGraw-Hill Irwin.

Oakland, J.S. (2000). Total quality management: Text with cases. (2nd edn.). Oxford: Butterworth-Heinemann.

Oakland, S., \& Oakland, J.S. (2001). Current people management activities in world-class organizations. Total Quality Management, 12(6), 773-788.

Ozgener, S. (2003). Quality function deployment: A teamwork approach. TQM and Business Excellence, 14(9), 969-979.

Quinn, R.E. (1988). Beyond rational management: Mastering the paradoxes and competing demands of high performance. San Francisco: Jossey-Bass.

Quinn, R.E., Faerman, S.R., Thompson, M.P., \& McGrath, M.R. (2003). Becoming a master manager: A competency framework. (3rd edn.). New York: John Wiley.

Rausch, E. (1980). How to make a goals program successful? Training and Development Journal, 34(3), 24-28.

Robbins, R.P. (2003). Organizational behavior. (10th edn.). Upper Saddle River: Prentice Hall.

Sashkin, M. (1984). Participative management is an ethical imperative. Organizational Dynamics, 12(4), 5-22.

Sinha, K.K., \& Van de Ven, A.H. (2005). Designing work within and between organizations. Organization Science, 16(4), 389408.
Smale, B.J.A., \& Frisby, W. (1990). Managerial competencies of municipal recreationists in Ontario. In Leisure challenges: Bringing people, resources and policy into play, Proceedings of the Sixth Canadian Congress on Leisure Research, 9-12 May 1990 (pp. 1-4). Ontario: Research Council on Leisure.

Spallina, J.M. (2004). Strategic planning - getting started: Mission, vision, and values. The Journal of Oncology Management, 13(1), 10-11.

Strebler, M., Thompson, M., \& Heron, P. (1997). Skills, competencies and gender: Issues for pay and training. Report 333, Institute of Employment Studies, 1-3.

Tushman, M.L., \& Anderson, P. (2004). Managing strategic innovation and change. (2nd edn.). New York: Oxford University Press.

Vora, M.K. (2004). Creating employee value in a global economy through participation, motivation and development. Total Quality Management, 15(5-6), 793-806.

Whetten, D.A., \& Cameron, K.S. (2005). Developing management skills. (6th edn.). New Jersey: Pearson Education.

Winfield, P.R., Bishop, R., \& Porter, K. (2004). Core management for HR students and practitioners. (2nd edn.). Oxford: Elsevier Butterworth-Heinemann. 